\title{
Heavy metal pollution from dust deposits in urban and industrial areas in the Jiul Valley
}

\author{
Andrei Szollosi-Moța ${ }^{1 *}$, Maria Prodan $^{1}$, Vasilica Irina Nălboc ${ }^{1}$, Sonia Niculina Șuvar ${ }^{1}$, and \\ Nicolae Ianc $^{1}$ \\ ${ }^{1}$ National Institute for Research And Development for Mine Safety and Protection to Exlosion - \\ Insemex, Department of Safety Mineral Resources, 32-34 G-ral Vasile Milea, Petrosani, Romania
}

\begin{abstract}
The aim of this paper was to determine the concentration of heavy metals in dust samples by the method of analysis by inductively coupled plasma optical emission spectrometry (ICP-OES) and to assess the degree of pollution of the studied areas. The dust samples studied and subjected to analytical analyzes were collected from the vicinity of industrial areas and urban areas of localities in the Jiu Valley, a monoindustrial area. The main heavy metals determined were: $\mathrm{Cu}, \mathrm{Zn}, \mathrm{Pb}$, $\mathrm{Ni}, \mathrm{Cr}, \mathrm{Co}$ etc. Dust particles depending on their origin can be inorganic or organic. The samples were collected from the urban areas and from the vicinity of the industrial areas.
\end{abstract}

\section{Introduction}

The main sources of soil and air pollution with dust are associated with the various phases of mining or industrial technological flows that took place in the Jiu Valley: exploitation of useful minerals, transport of minerals or fossil fuels, preparation and storage processes in dumps, which have formed landfills. In recent decades, the share of industrial activities has decreased significantly due to the mine closure process [1]. Soils can be polluted due to physical and chemical factors: change of land use by excavation and processing of ore extraction and transport of ore and tailings, storage of tailings from mining operations in dumps and processes resulting from ore processing. In the vicinity of tailings dumps and tailings ponds, tailings entrainment processes take place through meteorological factors, wind, rain, floods, etc. [2]. The composition of street and surface dust is influenced by the various sources from which it comes: materials transported by water, soil erosion processes, ash and carbon black deposits (soot) resulting from the use of fossil fuels in electricity production, building wear, wear of asphalt and sidewalks, degradation of vehicle tires, wear of brake pads, operation of internal combustion engines, loss of engine oil, etc. [3]. Heavy metals together with other toxic substances have a negative effect even in extremely low concentrations, these effects vary depending on the mode and duration of exposure and metabolism and the detoxification capacity of each body.

\footnotetext{
* Corresponding author: andrei.szollosi@insemex.ro
} 
Toxic mechanisms are varied and may include: inhibition of enzymatic processes, damage to cell membranes, as well as changes in transport processes and decreased neuronal function [4]. So, one of these effects are synergistic with other toxic elements or chemicals [5]. Metals can be chemically characterized as elements that conduct electricity, have a metallic luster and are malleable and ductile. Metals will react in different environments and some of them are dangerous for health or for (cadmium, lead, chromium), some can cause corrosion (for example (zinc, lead), and some metals are harmful in other ways [6]. Some of these elements are necessary for people in low amounts (chromium, manganese, copper) while others are carcinogenic or toxic, affecting the central nervous system (lead, arsenic, manganese), kidneys or liver (lead, cadmium, copper) or leather, bones (nickel, cadmium, chromium) [7]. Heavy metals cannot be biologically degraded, and can only be transformed from one state of oxidation or organic complex to another. The ways in which environmental factors are polluted by anthropogenic activities such as mining, purification of zinc, lead and cadmium, burning fossil fuels, burning waste, discharges from industrial effluents, or excessive use of fertilizers in agriculture [8]. By precipitating compounds or by ion exchanges in soils and muds, heavy metal pollutants can be located and left hidden in road dust [9]. Along with heavy metals in dust and street dust deposits can be found other contaminants such as silicon dioxide, [10] various oils such as oils, organic and inorganic compounds, bacteria and viruses [11].

\section{Materials and methods}

The collection of street dust samples was carried out in March 2021. The street samples were collected in clean polyethylene bags, the GPS system was used to mark the points from which the samples were collected (Table 1, Figure 1).

Table 1. Dust collection sites.

\begin{tabular}{|c|c|}
\hline Sampling point & Coordinates \\
\hline P1 & $\mathrm{N} 45^{\circ} 25^{\prime} 38^{\prime \prime}$ \\
\hline Road E66 & E $23^{\circ} 22^{\prime} 6^{\prime \prime}$ \\
\hline P2 & $\mathrm{N} 45^{\circ} 44^{\prime} 16^{\prime \prime}$ \\
\hline Petrila main road & Е $23^{\circ} 37^{\prime} 7^{\prime \prime}$ \\
\hline P3 & $\mathrm{N} 45^{\circ} 25^{\prime} 9^{\prime \prime}$ \\
\hline Petrosani University & E $23^{\circ} 22^{\prime} 36^{\prime \prime}$ \\
\hline P4 & N 4525'14" \\
\hline Station-colony & E $23^{\circ} 21^{\prime} 56^{\prime \prime}$ \\
\hline P5 & $\mathrm{N} 45^{\circ} 25^{\prime} 8^{\prime \prime}$ \\
\hline Maleia vicinity & E $23^{\circ} 22^{\prime} 20^{\prime \prime}$ \\
\hline P6 & $\mathrm{N} 45^{\circ} 24^{\prime} 13^{\prime \prime}$ \\
\hline Livezeni railway & E $23^{\circ} 22^{\prime} 25^{\prime \prime}$ \\
\hline P7 & $\mathrm{N} \mathrm{45^{ \circ } 2 3 ^ { \prime } 4 3 ^ { \prime \prime }}$ \\
\hline Dacia Square & E $23^{\circ} 22^{\prime} 31^{\prime \prime}$ \\
\hline P8 & $\mathrm{N} \mathrm{45^{ \circ } 2 3 ^ { \prime } 3 6 ^ { \prime \prime }}$ \\
\hline Petrosani Stadium & E $23^{\circ} 22^{\prime} 12^{\prime \prime}$ \\
\hline P9 & $\mathrm{N} 45^{\circ} 24^{\prime} 2 "$ \\
\hline Independentei Street Petroșani & E $23^{\circ} 22^{\prime} 36^{\prime \prime}$ \\
\hline P10 & $\mathrm{N}^{\circ 5^{\circ} 23^{\prime} 51^{\prime \prime}}$ \\
\hline Petrosani Carpathians neighborhood & $\mathrm{E} 23^{\circ} 22^{\prime} 19^{\prime \prime}$ \\
\hline P11 & $\mathrm{N} 45^{\circ} 24^{\prime} 47^{\prime \prime}$ \\
\hline Central ParkCarol Schreter vicinity & $\mathrm{E} 23^{\circ} 22^{\prime} 24^{\prime \prime}$ \\
\hline P12 & $\mathrm{N} \mathrm{45^{ \circ } 2 4 ^ { \prime } 4 9 ^ { \prime \prime }}$ \\
\hline Vulcan Main & E $23^{\circ} 22^{\prime} 11^{\prime \prime}$ \\
\hline
\end{tabular}




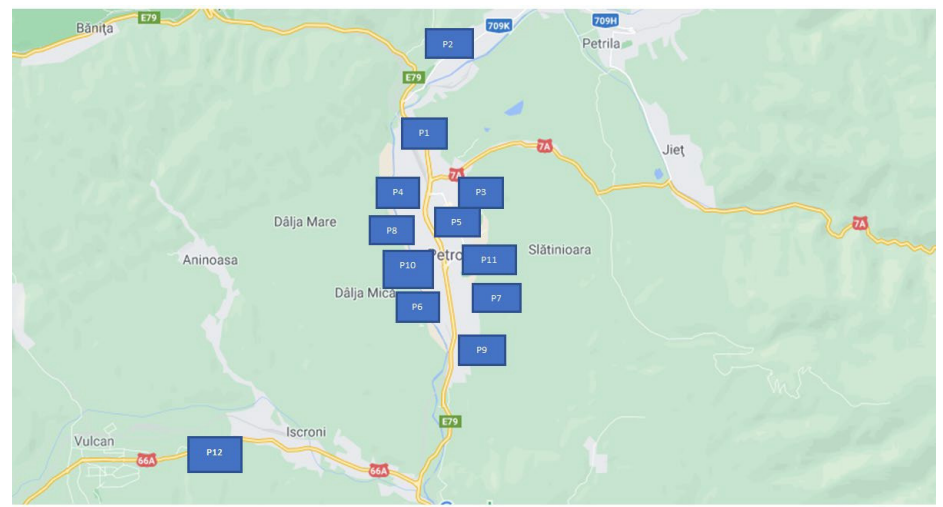

Fig. 1. Dust collection sites.

Street dust samples were taken from three different urban locations, low-traffic streets, high-traffic streets, parks area, residential and industrial areas in Petroșani, Petrila Vulcan, as well as one soil sample collected from Petrosani area, in order to establish background concentrations. Samples were analyzed for $\mathrm{As}, \mathrm{Co}, \mathrm{Cr}, \mathrm{Cu}, \mathrm{Mn}, \mathrm{Ni}, \mathrm{Pb}, \mathrm{Zn}, \mathrm{Ti}, \mathrm{Fe}$ using the inductively coupled plasma atomic emission (ICP OES) spectrophotometric technique (Figure 2).

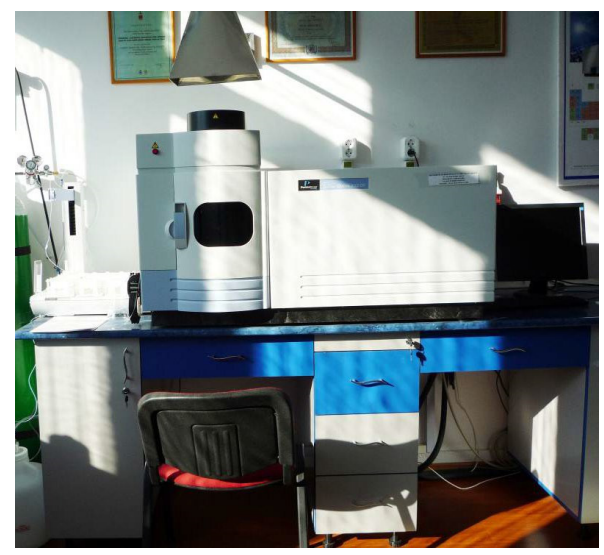

Fig. 2. ICP-OES spectrometer.

\section{Results and discussion}

One must pay special attention to heavy metal pollution associated with urban dust particles, amid overwhelming concerns about heavy metals could have a considerable impact on the ecosystem and human health.

The main localities in the Jiu Valley are: Petrila, Petroșani, Aninoasa, Vulcan, Lupeni, Uricani. The position of the points used for sampling was determined using the GPS system. Samples of dust particles were taken from urban locations in Petroșani, but also Petrila and Vulcan from different areas, with different characteristics of traffic, heavy and low traffic, areas near industrial perimeters, residential neighborhoods, recreational areas, etc. Soil sample was also analyzed, which was considered a reference in the given situation. The collected street dust samples were analyzed by inductively coupled plasma optical emission spectrometry. The samples were homogenized, crushed, sieved and mineralized using the microwave mineralizer at temperatures between $170^{\circ} \mathrm{C}$ and $200^{\circ} \mathrm{C}$, using high 
purity nitric acid, after mineralization and cooling of the resulting solution it was transferred to volumetric flasks of $100 \mathrm{ml}$.

In the Tables 2 and 3 there are the values obtained for heavy metals from the dust samples analyzed.

Table 2. Values obtained for heavy metals.

\begin{tabular}{|c|c|c|c|c|c|}
\hline Sample & As mg ${ }^{k g}{ }^{-1}$ & Co mg $\mathrm{kg}^{-1}$ & Cr mg $k^{-1}$ & Cu mg.kg-1 & Mn mg.kg-1 \\
\hline P1 & 8.717 & 2.213 & 39.39 & 38.00 & 470.2 \\
\hline P2 & 4.844 & 1.926 & 22.13 & 21.89 & 331.0 \\
\hline P3 & 6.195 & 2.106 & 13.48 & 15.08 & 347.2 \\
\hline P4 & 9.030 & 2.489 & 20.80 & 16.50 & 298.1 \\
\hline P5 & 4.741 & 2.670 & 19.65 & 21.88 & 265.8 \\
\hline P6 & 9.519 & 3.511 & 28.40 & 33.88 & 375.5 \\
\hline P7 & 2.748 & 2.975 & 17.10 & 14.74 & 294.5 \\
\hline P8 & 8.401 & 3.325 & 28.66 & 27.87 & 347.7 \\
\hline P9 & 9.324 & 2.953 & 14.98 & 8.986 & 204.1 \\
\hline P10 & 5.854 & 2.634 & 30.36 & 33.53 & 410.1 \\
\hline P11 & 5.925 & 3.103 & 31.41 & 35.03 & 429.8 \\
\hline P12 & 5.843 & 2.308 & 23.92 & 26.39 & 323.7 \\
\hline Average & 6.761 & 2.684 & 24.19 & 24.48 & 341.48 \\
\hline
\end{tabular}

Table 3. Values obtained for heavy metals.

\begin{tabular}{|c|c|c|c|c|c|}
\hline Sample & $\mathrm{Ni} \mathbf{m g} \cdot \mathrm{kg}^{-1}$ & $\begin{array}{c}\mathrm{Pb} \\
\text { mg.kg-1 }\end{array}$ & $\mathrm{Zn} \mathrm{mg} \cdot \mathrm{kg}^{-1}$ & Ti mg $\mathbf{k g}^{-1}$ & $\mathrm{Fe} \mathrm{mg} \mathrm{kg}^{-1}$ \\
\hline P1 & 11.52 & 3.091 & 79.32 & 463.3 & 14360 \\
\hline P2 & 9.517 & 1.604 & 79.19 & 317.0 & 13840 \\
\hline P3 & 6.276 & 5.665 & 74.11 & 115.8 & 6546 \\
\hline P4 & 9.926 & 10.11 & 89.62 & 414.1 & 13990 \\
\hline P5 & 9.509 & 4.954 & 81.38 & 256.2 & 12620 \\
\hline P6 & 18.02 & 9.509 & 111.4 & 393.0 & 14420 \\
\hline P7 & 10.90 & 14.06 & 115.5 & 271.8 & 9567 \\
\hline P8 & 13.63 & 7.650 & 78.22 & 400.0 & 14560 \\
\hline P9 & 7.964 & 9.683 & 116.8 & 271.7 & 7741 \\
\hline P10 & 14.71 & 7.964 & 124.6 & 396.5 & 19400 \\
\hline P11 & 15.70 & 8.038 & 128.8 & 410.9 & 19920 \\
\hline P12 & 11.71 & 6.422 & 97.30 & 310.22 & 15120 \\
\hline Average & 11.61 & 7.39 & 98.02 & 335.04 & 13507 \\
\hline
\end{tabular}

Using the Index Pollution formula (1) [12], it was evaluated the degree of pollution (Table 4) in the analyzed samples (Table 5).

$$
\text { IP }=\text { Cdet. } / \text { Crefer }
$$

where:

Cdet - concentration of the studied element;

Crefer - reference concentration.

Table 4. Pollution index values.

\begin{tabular}{|c|c|c|}
\hline Pollution & Category & IP \\
\hline Unpolluted & I & IP $<1$ \\
\hline Slightly polluted & II & $1<$ IP $\leq 2$ \\
\hline Moderately polluted & III & $2<$ I P $\leq 3$ \\
\hline Heavily polluted & IV & $3<$ IP \\
\hline
\end{tabular}


Table 5. The range of values for the pollution index in the analyzed samples.

\begin{tabular}{|c|c|}
\hline Metals & Range of values \\
\hline $\mathrm{As}$ & $0.37 \div 1.28$ \\
\hline $\mathrm{Co}$ & $0.11 \div 1.92$ \\
\hline $\mathrm{Cr}$ & $0.67 \div 1.97$ \\
\hline $\mathrm{Cu}$ & $0.55 \div 1.42$ \\
\hline $\mathrm{Mn}$ & $0.47 \div 1.08$ \\
\hline $\mathrm{Ni}$ & $0.15 \div 0.29$ \\
\hline $\mathrm{Pb}$ & $0.33 \div 2.95$ \\
\hline $\mathrm{Zn}$ & $0.69 \div 1.21$ \\
\hline
\end{tabular}

In the Table 6 is given the range of determined concentration for the dust samples versus the fond concentration in the analyzed soil sample.

Table 6. Range of determined concentrations.

\begin{tabular}{|c|c|c|c|}
\hline Metal & $\begin{array}{c}\text { Wavelength } \\
\text { nm }\end{array}$ & $\begin{array}{c}\text { The concentration } \\
\text { range of road dust } \\
\text { samples } \\
\text { mg.kg-1 }\end{array}$ & $\begin{array}{c}\text { The fond } \\
\text { concentration of } \\
\text { metals in soil } \\
\text { samples } \\
\text { mg.kg-1 }\end{array}$ \\
\hline $\mathrm{As}$ & 199.696 & $2.748 \div 9.519$ & 7.46 \\
\hline $\mathrm{Co}$ & 228.802 & $1.92 \div 33.325$ & 17.38 \\
\hline $\mathrm{Cr}$ & 267.716 & $13.48 \div 39.39$ & 20.02 \\
\hline $\mathrm{Cu}$ & 327.393 & $14.74 \div 38$ & 26.76 \\
\hline $\mathrm{Mn}$ & 257.610 & $204.14 \div 470$ & 437 \\
\hline $\mathrm{Ni}$ & 231.604 & $7.96 \div 15.7$ & 54.4 \\
\hline $\mathrm{Pb}$ & 220.353 & $1.6 \div 14.06$ & 4.775 \\
\hline $\mathrm{Zn}$ & 213.857 & $74.11-128.8$ & 106.8 \\
\hline $\mathrm{Ti}$ & 334.94 & $256.2-463.3$ & 484.2 \\
\hline $\mathrm{Fe}$ & 238.204 & $6546-19920$ & 21332 \\
\hline
\end{tabular}

In the Figure 3 it can be seen the variation of metal concentrations in the case of the analyzed samples.

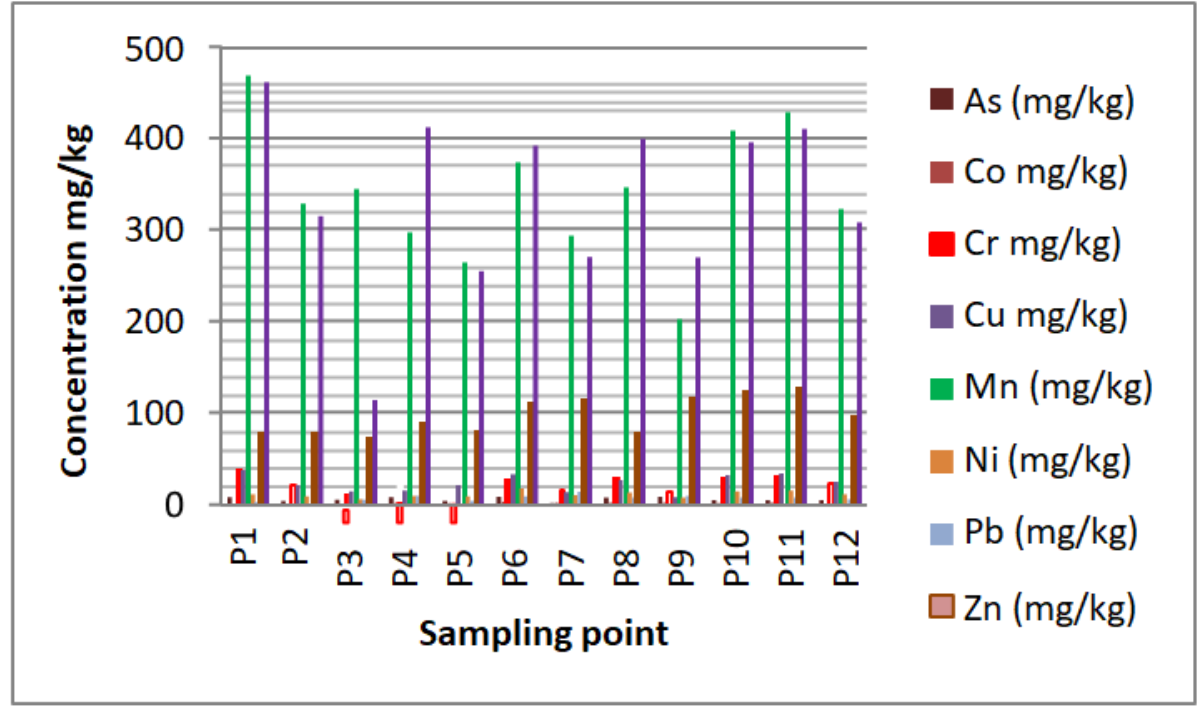

Fig. 3. Variation of metal concentrations in the case of the analyzed samples. 
Thus, in the case of manganese, the determined concentrations were between 204.14 and $470.2 \mathrm{mg} . \mathrm{kg}^{-1}$, with an average concentration of $341.48 \mathrm{mg} \cdot \mathrm{kg}^{-1}$. The average concentration determined in the case of chromium is $24.19 \mathrm{mg} \cdot \mathrm{kg}^{-1}$, with values of concentrations between 13.48 and $39.39 \mathrm{mg} \cdot \mathrm{kg}^{-1}$. In the case of manganese samples, a slight concentration was observed compared to the soil sample taken as a reference. In the case of arsenic, values between $2,748 \div 8,717 \mathrm{mg} \cdot \mathrm{kg}^{-1}$ were obtained, being observed an enrichment of the dust samples in the arsenic element. In the case of chromium, values between $13.48 \div 39.39 \mathrm{mg} \cdot \mathrm{kg}^{-1}$ were determined, higher values could also be observed in the case of some of the samples.

For the copper element, the values determined in the street dust samples were between $14.74 \div 38 \mathrm{mg} \cdot \mathrm{kg}^{-1}$, thus an enrichment of the dust in the copper content of the soil taken as reference can be observed. Analyzing the zinc content, it can be seen that compared to the values $74.11-128.8 \mathrm{mg} \cdot \mathrm{kg}^{-1}$ obtained, there was a slow increase in the concentration of some analyzed street dust samples, compared to the soil concentration considered as a reference. In the case of lead, an average value of $7.39 \mathrm{mg} \cdot \mathrm{kg}^{-1}$ was determined and an enrichment of it was observed compared to the lead content of the soil sample taken as reference, the values being in the range $1.6 \div 14.06 \mathrm{mg}^{\mathrm{kg}}{ }^{-1}$. For the nickel concentration, no increase in concentrations was observed in the street dust samples subjected to analyzes compared to the reference concentrations.

\section{Conclusions}

Urban dust deposits (street dust) represent the image of a wide range of anthropogenic activities and are a useful resource for assessing the level and distribution of heavy metal contaminants in the surface environment. The highest level of metals were found in the samples from the industrial area and the streets where there is heavy traffic and the vicinity of the industrial units the lowest in the areas with low traffic and industrial activity.

Concentrations and levels of contamination of $\mathrm{Zn}, \mathrm{Cu}, \mathrm{Pb}, \mathrm{Mn}, \mathrm{Cr}$ and $\mathrm{Co}, \mathrm{Ni}$, As were studied in the street dust collected in the urban and industrial areas of the Jiu Valley, being evaluated the pollution index.

The concentrations determined for certain samples were higher than their background values, at the indicators $\mathrm{As}, \mathrm{Co}, \mathrm{Cr}, \mathrm{Cu}, \mathrm{Mn}, \mathrm{Pb}, \mathrm{Zn}$.

If we analyze the average values of metal concentrations, we can see that in the case of chromium and lead, the average values of sample concentration were higher compared to their background values. In the case of the other elements (As, $\mathrm{Co}, \mathrm{Cu}, \mathrm{Mn}, \mathrm{Zn}$ ) the average values obtained had lower values than the background values.

The values of the pollution index varied in the following order: $\mathrm{Pb}>\mathrm{Cr}>\mathrm{Co}>\mathrm{Cu}>\mathrm{As}>$ $\mathrm{Mn}>\mathrm{Ni}$. These values of the pollution index showed that the street dust particles in the Jiu Valley in terms of $\mathrm{Pb}$ and $\mathrm{Cr}$ concentrations were moderately contaminated, the dust indicated that there is considerable pollution with $\mathrm{Pb}$, which mainly from traffic and industrial activities.

This paper was developed within the NUCLEU - Programme, carried out with the support of ANCSI, Project no. PN-19 210103.

\section{References}

1. M. Philip, H. Louis, T. Magu, T. Fidelis, O.N. Mateira, I. Opara, Journal of Environmental \& Analytical Toxicology, 7 (3), 1-4 (2017)

2. A.J. Kim, J.H. Park, W.J. Hwang, Int. J. Environ. Res. Public Health, 13 (8), 820 (2016)

3. K. Nazriddinzoda, I. Blinov, A. Pavel, E3S Web of Conferences CADUC 2019, 99, 1-3 (2019) 
4. A. Simion, A.N. Călămar, L. Toth, M. Kovacs, S. Simion, Annals of the University of Petroșani, Universitas Publishing House-Petrosani (Romania), 19 (2018)

5. S. Dytlow, B. Go'rka-Kostrubiec, Environ Geochem Health, 43, 521-535 (2021)

6. E.C. Rada, G. Ionescu, F. Conti, I.L. Cioca, V. Torretta, Quality Access to Success. 19, No.167, 112-118 (2018)

7. D. Goossens, Earth Surf. Process. Landforms 26, 1213-1219 (2001)

8. A. Tulbure, C.A. Danciu, Quality Access to Success, 20, No. 169, (2018)

9. Y. Nazzal, M. Grefat Habbes, A. Rosen, Research of Environmental Sciences, 8 (5), 259-273 (2014)

10. L. Mărmureanu, A.C. Marin, S. Andrei, B. Antonescu, D. Ene, M. Boldeanu, I. Vasilescu, C. Vițelan, O. Cadar, E. Levei, Advanced in Measurement and Modelling of the Eart's Minerals, Dust Source,21, 2466, (2019)

11. A. Razanica, J. Huremovivi, S. Zero, S. Gojak-Salimovic, H. Memic, Current World Environment, 9 (1), 43-47, (2014)

12. M. Hemati, G. Rahimi, Biomedical Journal of Scientific \& Technical Research, 30, $2574-124$ (2020) 